\title{
Studi Korelasi Motivasi Pemilihan Program Studi dengan Prestasi Mahasiswa Politeknik Negeri Tanah Laut Tahun Ajaran 2018/2019
}

\author{
Tekad Budiantoro $^{1)}$, Wan Yuliyanti ${ }^{2)}$, Karolina $^{3)^{*}}$ \\ Akuntansi ${ }^{13)}$, Teknik Informatika ${ }^{2}$, Politeknik Negeri Tanah Laut \\ email*): karolina@politala.ac.id
}

\begin{abstract}
Abstrak
Prestasi mahasiswa baik secara akademik maupun non akademik menjadi titik perhatian seluruh civitas akademika Politeknik Negeri Tanah Laut. Prestasi akademik juga menjadi komponen penting dalam pendidikan vokasi, karena dapat dijadikan sebagai parameter untuk menilai apakah lulusan memiliki kompetensi yang cukup sehingga mampu melakukan pekerjaan sesuai jurusan dan bidang keahliannya.

Subjek dalam penelitian ini adalah mahasiswa Politeknik Negeri Tanah Laut tahun ajaran 2018/2019. Penelitian ini dilakukan dengan menggunakan sistem random sampel.

Hasil dari penelitian dapat diinterpretasikan bahwa tidak ada hubungan yang signifikan antara motivasi pemilihan program studi dengan prestasi akademik, begitu juga sebaliknya prestasi akademik mahasiswa tidak ditentukan oleh motivasi dalam memilih program studi.
\end{abstract}

\section{Kata Kunci: motivasi, program studi, prestasi mahasiswa}

\begin{abstract}
Students' achievement, either in academic or non-academic, becomes a point of concern to academic society in State Polytechnic of Tanah Laut. Academic achievement becomes an important part in vocational education as well, because it could be a parameter to evaluate if the graduate has enough competency to work related to his major and competence.

Subject of this research was State Polytechnic of Tanah Laut students from academic year 2018/2019. The research was conducted by using random sampling.

The result of the research could be interpreted that there is no significant correlation between motivation in deciding major and academic achievement. On the contrary, students' academic achievement could not be affected by motivation in deciding major.
\end{abstract}

Keywords: $\quad$ motivation, major, students' achievement 


\section{PENDAHULUAN}

Prestasi mahasiswa, baik secara akademik maupun non akademik, menjadi titik perhatian seluruh civitas akademika Politeknik Negeri Tanah Laut. Syah (2011) menyatakan bahwa prestasi akademik mahasiswa adalah prestasi akademik dalam perkuliahan yang relatif bersifat permanen setelah melalui proses belajar dalam jangka waktu tertentu. Prestasi akademik juga menjadi komponen penting dalam pendidikan vokasi, karena dapat dijadikan sebagai parameter untuk menilai apakah lulusan memiliki kompetensi yang cukup sehingga mampu melakukan pekerjaan sesuai jurusan dan bidang keahliannya. Sugiyanto (2009) mengungkapkan pada penelitiannya bahwa dengan memiliki kompetensi yang sesuai dengan bidang ilmu yang dipelajari, maka kualitas mahasiswa akan diakui dunia industri yang menjadi pasar bagi lulusan perguruan tinggi.

Ada beberapa faktor yang mempengaruhi mahasiswa dalam mencapai prestasi akademiknya. Marlianto Pangestu Catur dalam jurnal penelitiannya membuat simpulan bahwa faktor-faktor yang memengaruhi prestasi akademik mahasiswa antara lain karakteristik mahasiswa, gaya hidup, kebiasaan belajar, motivasi, dan status sosial ekonomi (Catur, 2018). Selain itu, Adjani dan Adam (2013) juga mengadakan penelitian dengan menggunakan empat faktor dalam mengukur prestasi mahasiswa, yakni pengalaman belajar, motivasi, lingkungan keluarga, dan kualitas pengajaran.

Senada dengan simpulan tersebut, Slameto (2010:54) mengemukakan faktor-faktor yang mempengaruhi prestasi belajar pada diri seseorang, yaitu faktor internal berupa jasmani dan kejiwaan, kemudian faktor eksternal meliputi keadaan keluarga, sekolah dan masyarakat.

Terkait hal tersebut, terutama faktor internal yang dapat mempengaruhi prestasi belajar, maka pada kesempatan ini peneliti tertarik untuk mengkaji seputar korelasi antara motivasi mahasiswa dalam memilih program studi dengan prestasi akademik yang mereka capai pada lingkup Politeknik Negeri Tanah Laut. Permasalahan yang akan dicari jawabannya dalam penelitian ini adalah sebagai berikut :

a. Apakah ada korelasi signifikan antara motivasi pemilihan program studi dengan prestasi akademik mahasiswa Politeknik Negeri Tanah Laut Tahun Ajaran 2018/2019?

b. Bagaimana arah korelasi antara motivasi pemilihan program studi dengan prestasi akademik mahasiswa Politeknik Negeri Tanah Laut Tahun Ajaran 2018/2019?

\section{TINJAUAN PUSTAKA}

\section{Faktor Prestasi}

Slameto (2010:54) mengemukakan secara rinci faktor-faktor yang mempengaruhi prestasi belajar pada diri seseorang, yaitu:

\section{a. Faktor dari dalam (Internal)}

Yaitu faktor pengaruh yang bersumber dari dalam diri sendiri, antara lain:

1) Faktor fisik jasmani seseorang, seperti :

a. Kesehatan

Kondisi kesehatan seseorang akan sangat berpengaruh terhadap kelancaran proses belajar, jika kesehatan terganggu maka aktivitas belajarpun akan terganggu, loyo, cepat lelah, kurang semangat, pusing, mengantuk, dan kurang konsentrasi.

b. Cacat badan

Cacat badan seperti kebutaan, tuli, cacat kaki, cacat tangan.

2) Faktor psikologis atau kejiwaan seseorang, meliputi :

a. Kecerdasan atau IQ 
Seseorang yang mempunyai tingkat kecerdasan atau IQ yang tinggi cenderung lebih mudah mempelajari sesuatu dibandingkan dengan mereka yang mempunyai tingkat kecerdasan atau IQ rendah.

b. Perhatian

Seseorang yang mempunyai perhatian tinggi, pada umumnya lebih fokus pada sesuatu yang dipelajarinya. Agar sesorang dapat belajar dengan baik serta mencapai hasil yang baik maka harus menaruh perhatian secara sungguh-sungguh, tidak hanya sambil lalu.

c. Minat

Minat seseorang terhadap sesuatu akan menimbulkan ketertarikan dan kesukaan terhadap sesuatu, hal demikian sangat menguntungkan bagi proses pembelajaran.

d. Bakat

Yaitu potensi dasar bawaan yang dimiliki oleh seseorang. Potensi tersebut akan berkembang menjadi kecakapan yang nyata sesudah seseorang berlatih, dengan kata lain bakat seseorang akan terasah melaluikegiatan belajar.

e. Motivasi

Motivasi adalah dorongan yang timbul dari dalam diri seseorang. Berkat motivasi itulah seseorang terdorong untuk dengan rela hati dan sungguh-sungguh melakukan sesuatu. Begitu juga dalam kegiatan belajar, seseorang akan belajar dengan sungguh-sungguh jika ia mempunyai motivasi yang cukup.

f. Kesiapan

Kesiapan adalah kesediaan seseorang untuk menerima informasi atau bahan belajar dan memberikan respon atau reaksiaksi. Kesiapan yang baik merupakan modal awal bagi berhasilnya proses belajar.

\section{b. Faktor dari luar diri pembelajar (Eksternal)}

Faktor ini meliputi hal-hal dan keadaan di luar individu yang bersangkutan, seperti:
a. Keadaan keluarga
b. Keadaan sekolah
c. Keadaan masyarakat

\section{Teori Motivasi}

Dzaki (2009) mengemukakan beberapa teori motivasi, antara lain hedonisme, naluri, teori reaksi, teori pendorong, dan teori kebutuhan. Sejalan dengan motivasi yang dimiliki mahasiswa, maka disini ditekankan pada teori pendorong, yang mana memadukan antara teori naluri dengan teori reaksi. Seseorang melakukan sesuatu karena adanya daya dorong dari dirinya. Daya dorong dari dalam diri ini penting dalam belajar, baik yang timbul karena naluri maupun daya dorong yang timbul karena reaksi atas lingkungan sekitarnya. Menurut teori ini, seorang pendidik atau pemimpin akan efektif melakukan perubahan apabila mampu membangkitkan dorongan belajar dari pembelajar atau orang yang dipimpinnya.

Selain itu, Pravesti (2016) menyimpulkan bahwa motivasi belajar adalah dorongan yang berhubungan dengan prestasi akademik mahasiswa, yakni dorongan ingin tahu, dorongan ingin sukses, dan dorongan ingin bekerja sama dalam melakukan aktivitas belajar guna mencapai tujuan belajar. Jika tidak ada dorongan, maka mahasiswa tidak memiliki motivasi dalam mengikuti pembelajaran di kampus. Hal ini tentu akan berdampak pada pencapaian prestasi akademik mahasiswa tersebut. 


\section{Klasifikasi Motivasi}

Secara kuantitatif motivasi dapat dikelompokkan sebagai berikut:

\section{a. Motivasi Tinggi}

Motivasi seseorang untuk melakukan sesuatu disebut tinggi apabila ia menaruh harapan yang tinggi dan positif atas upaya yang dilakukannya. Selain itu ia mempunyai keyakinan bahwa upaya-upaya yang dilakukan akan berhasil dan membawa manfaat bagi dirinya, baik di masa sekarang maupun di masa yang akan datang. Dengan keyakinannya tersebut, ia akan sanggup melakukan sesuatu secara sungguhsungguh, gigih, ulet, gembira, dan rela hati. Dalam Skala Likert, termasuk kriteria motivasi tinggi apabila berada pada angka (67-100\%)

\section{b. Motivasi Sedang}

Dikelompokkan pada motivasi sedang, apabila dalam melakukan sesuatu seseorang memiliki keinginan dan harapan yang positif dan tinggi, tetapi tidak mempunyai keyakinan yang kuat bahwa ia akan berhasil. Orang-orang pada kategori ini pada umumnya mereka tidak yakin betul bahwa akan mampu mengatasi segala persoalan dan ujian yang dihadapi, sehingga dalam melakukan upaya biasanya masih diwarnai kebimbangan dan keraguan. Dalam Skala Likert, termasuk kriteria motivasi sedang apabila berada pada angka (34 - $66 \%)$

\section{c. Motivasi Rendah}

Masuk dalam kelompok ini adalah orang-orang yang memiliki harapan dan keyakinan yang rendah terhadap upaya yang dilakukannya. Mereka tidak yakin benar bahwa akan mampu mengatasi segala persoalan dan ujian, hingga meraih keberhasilan. Mereka juga tidak yakin bahwa mereka bisa meraih prestasi, bahkan kadang mempunyai keyakinan bahwa suatu prestasi tidak akan membawa manfaat pada dirinya. Pembelajar pada kelompok ini pada umumnya kurang bersungguh-sungguh dalam berupaya, suka menghindar dari segala tugas yang dianggapnya sulit, aktivitas pembelajaran diikuti hanya karena memang harus diikuti tidak ada keinginan untuk menguasai ilmu yang sedang dipelajarai. Dalam Skala Likert, termasuk kriteria motivasi rendah apabila berada pada angka (0 - $33 \%)$

\section{Mengukur Motivasi}

Untuk mengetahui tingkatan motivasi seseorang tidak dapat dilihat dan nampak secara langsung, tetapi harus dilihat melalui sebuah pengukuran. Ada bebarapa cara yang dapat digunakan oleh para ahli untuk mengukur tingkat motivasi seseorang. Dalam kaitan ini Notoadmodjo mengemukakan yaitu dengan a) tes proyektif, b) kuesioner, dan c) perilaku (Notoadmodjo, 2010) seperti berikut:

a. Tes Proyektif

Tes ini mengukur dengan cara memproyeksikan antara apa yang diperbuat dan diucapkan seseorang dengan apa yang ada dalam hatinya. Ada keyakinan secara manusiawi, bahwa apa yang diucapkan seseorang adalah cerminan dari apa yang ada pada dirinya. Dengan kata lain untuk memahami apa yang dipikirkan seseorang, kita harus melakukan interpretasi terhadap perilaku-perilaku yang ditunjukkan. Salah satu contoh tes proyektif yang banyak dipakai orang adalah tes apersepsi atau Thematic Apperception Test (TAT). Pada pelaksanaan tes ini seseorang yang akan menjalani tes diberi sejumlah gambar untuk dipilih salah satu kemudian diminta untuk membuat cerita dari gambar tersebut. Dari isi cerita yang dikemukakan itulah peneliti dapat menelaah motivasi apa yang ada pada diri klien tersebut. 


\section{b. Kuesioner}

Menghimpun data dengan kuesioner sudah lazim dipakai pada banyak penelitian. Dalam kaitannya dengan pengukuran motivasi, dilakukan dengan cara meminta kepada klien untuk mengisi kuesioner yang berisi sejumlah pertanyaan. Pertanyaan-pertanyaan tersebut dirancang untuk dapat memancing jawaban guna mengungkap motivasi klien.

Salah satu contoh yang sering dipakai peneliti adalah Edward's Personal Preference Schedule (EPPS). Kuesioner ini terdiri atas sejumlah pasang pertanyaan yang berbeda-beda, klien diminta oleh peneliti untuk memilih salah satu dari pasang pertanyaan tersebut yang klien rasa lebih mencerminkan keadaan dirinya. Dari hasil pengisian kuesioner tersebut peneliti melakukan analisis guna memperoleh kesimpulan motivasi apa yang ada pada diri sang klien.

\section{c. Observasi Perilaku}

Observasi perilaku adalah cara yang digunakan oleh peneliti untuk merangsang sedemikian rupa sehingga memunculkan perilaku klien secara alami dan apa adanya, yang kadang tidak disadari oleh klien itu sendiri. Dari perilaku-perilaku yang muncul itulah seorang peneliti melakukan analisis, guna mengungkap apa sesungguhnya motivasi klien.

\section{Prestasi Akademik}

Syah (2011) mendefinisikan prestasi akademik sebagai hasil interaksi dari sebagian faktor yang mempengaruhi proses belajar secara keseluruhan yang meliputi segenap ranah psikologis yang berubah sebagai akibat pengalaman dan proses belajar mahasiswa. Pravesti (2016) juga menambahkan bahwa prestasi akademik sejatinya adalah hasil akhir yang diharapkan dapat diperoleh setelah mahasiswa belajar. Hasil akhir ini meliputi tiga aspek, yakni tahu, mengetahui (knowing), terampil melaksanakan atau mengerjakan yang diketahui (doing), dan melaksanakan yang diketahui itu secara rutin dan konsekuen (being).

Prestasi akademik seorang mahasiswa diperoleh melalui proses belajar dari waktu ke waktu selama mengikuti kuliah. Tidak jauh beda dengan prestasi belajar, prestasi akademik seseorang dapat mengalami perubahan naik dan turun tergantung pada upaya dan kerja keras yang dilakukan. Mereka yang memiliki motivasi tinggi, tekun, sungguh-sungguh dalam belajar, dan tetap semangat dalam menghadapi berbagai persoalan dan ujian wajar jika memiliki prestasi akademik yang tinggi, demikian pula sebaliknya. Dengan kata lain, prestasi akademik seorang mahasiswa merupakan konskuensi logis dari kerja keras yang telah ia lakukan. Untuk mengetahui prestasi akademik seorang mahasiswa dapat dilakukan dengan berbagai pola ujian, seperti tugas portofolio, ujian tengah semester, ujian akhir semester dan sebagainya.

\section{METODE PENELITIAN}

\section{Waktu dan Tempat}

Penelitian dilaksanakan mulai bulan April sampai dengan bulan Desember 2019. Tempat penelitian dipusatkan pada kampus Politeknik Negeri Tanah Laut, Jl. A Yani KM. 6 Desa Panggung Kecamatan Pelaihari Kabupaten Tanah Laut.

\section{Subjek Penelitian}

Subjek penelitian dipilih dengan menggunakan sistem random sampling, yang mana pengambilan anggota sampel dari populasi yang dilakukan secara acak tanpa memperhatikan strata yang ada dalam populasi itu (Sugiyono, 2017:82). Subjek dalam penelitian ini adalah mahasiswa tahun pertama Politeknik Negeri Tanah Laut, yang dipilih secara acak dengan rincian sebagai berikut: 
1. Mahasiswa Program Studi Teknik Informatika (TI) yang terdiri dari 4 (empat) kelas dan akan dipilih 10 (sepuluh) orang dari masing-masing kelas.

2. Mahasiswa Program Studi Teknologi Industri Pertanian (TIP) yang terdiri dari 3 kelas dan akan dipilih 10 (sepuluh) orang dari masing-masing kelas.

3. Mahasiswa Program Studi Mesin Otomotif (MO) yang terdiri dari 2 kelas dan akan dipilih 10 (sepuluh) orang dari masing-masing kelas.

4. Mahasiswa Program Studi Akuntansi (AKT) yang terdiri dari 3 kelas dan akan dipilih 10 (sepuluh) orang dari masing-masing kelas.

Sehingga total mahasiswa yang menjadi subjek penelitian ini adalah 120 (seratus dua puluh) orang.

\section{Teknik Pengumpulan Data}

Mengingat bahwa penelitian ini bersifat studi korelasi, maka ada dua variabel utama yang menjadi bahan pokok analisis, yaitu motivasi pemilihan program studi dan dan prestasi akademik.

Data untuk memperoleh data tentang motivasi mahasiswa digali langsung dari mahasiswa sebagai subjek penelitian, dengan menggunakan teknik angket dan kuesioner. Sedangkan data tentang prestasi akademik mahasiswa diambil dari dokumen Daftar Nilai Akhir (DNA) mahasiswa yang menjadi subjek penelitian. Data nilai yang digunakan adalah data nilai yang sudah sah dan menjadi dokumen resmi pada Bagian Pengajaran Politeknik Negeri Tanah Laut.

\section{Analisis dan Pengolahan Data}

Seluruh data yang terkumpul yang berkaitan dengan motivasi pemilihan program studi yang dikumpulkan melalui angket dan kuesioner dipilih dan dipilah untuk diklasifikasikan sesuai dengan jenis dan isinya, untuk selanjutnya dilakukan tabulasi atau pentabelan. Analisis awal ini dilakukan guna memperoleh data penting tentang motivasi mahasiswa dalam memilih program studi. Skala Likert dengan kategori tinggi (3), sedang (2), dan rendah (1) digunakan untuk menganalisis data motivasi yang masuk.

Sebagai langkah akhir dari proses penelitian ini adalah menganalisis dua variabel utama yaitu motivasi pemilihan program studi dan prestasi akedemik mahasiswa. Analisis ini dilakukan untuk memperoleh gambaran sebagai berikut:

a. Adakah korelasi atau hubungan antara motivasi pemilihan program studi dengan prestasi akademik mahasiswa?

b. Bagaimana sifat korelasi antar keduanya, apakah motivasi yang positif juga akan berpengaruh secara positif terhadap prestasi akademik, atau sebaliknya?

Sebagai penunjang analisis tersebut, maka digunakan uji statistik yakni uji korelasi Kendalls Taub. Uji statistik dilaksanakan dengan bantuan SPSS. Uji Kendalls Tau-b dipilih karena kedua data yang akan di uji direpresentasikan dalam bentuk data ordinal.

\section{HASIL DAN PEMBAHASAN}

Tujuan pertama dari penelitian ini mendeskripsikan ada dan tidaknya korelasi antara motivasi pemilihan program studi dengan prestasi akademik mahasiswa Politeknik Negeri Tanah Laut Tahun Ajaran 2018/2019. Gambar 1 menunjukkan bagaimana sebaran dari tingkat motivasi pemilihan program studi. Pada diagram tersebut terlihat bahwa mahasiswa yang memikili motivasi tinggi ada sebesar 9\%. Mahasiswa yang memiliki motivasi pemilihan program studi yang sedang ada sebesar 53\%. Sisanya, yakni 38\% memiliki motivasi yang rendah ketika pemilihan program studi. 


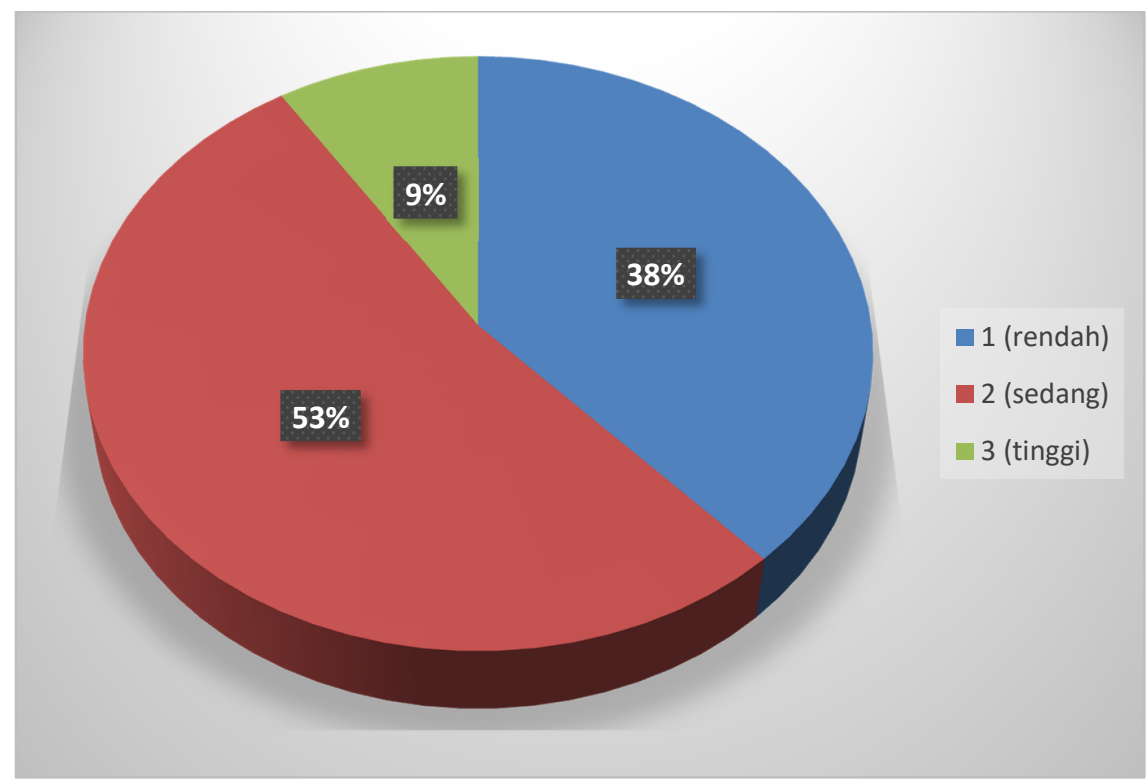

Gambar 1 Tingkat motivasi pemilihan program studi

Gambar 2 menunjukkan bagaimana tingkat prestasi akademik mahasiswa Politeknik Negeri Tanah Laut. Diagram tersebut menunjukkan bahwa $63 \%$ mahasiswa memiliki IPK yang berkategori tinggi. 33\% mahasiswa memperoleh IPK yang berkategori sedang. Sebagian kecil mahasiswa saja yang memiliki IPK dengan kategori rendah.

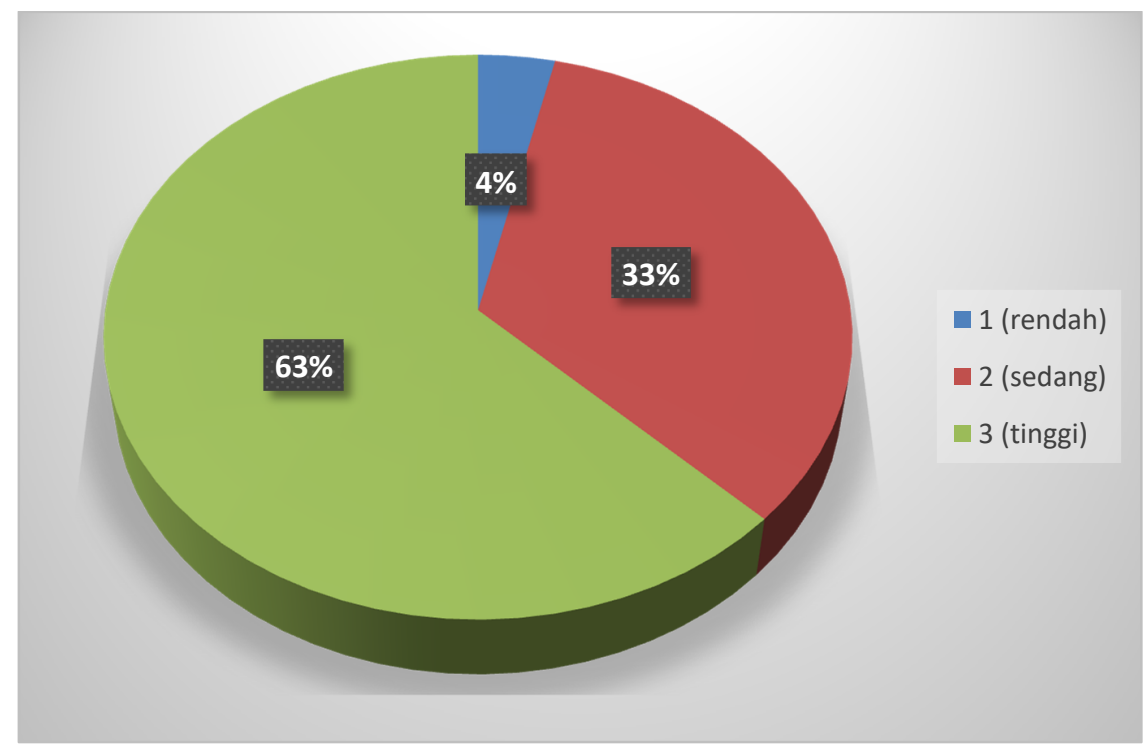

Gambar 2 Tingkat prestasi akademik

Dalam rangka memenuhi tujuan penelitian yang pertama, maka dilakukan lah uji korelasi Kendalls Tau - b. Uji ini dilakukan untuk mencari korelasi antara dua data ordinal yakni motivasi mahasiswa dan tingkat prestasi akademik mahasiswa. Tabel 1 menunjukkan hasil Uji Kendalls Tau-b. 
Tabel 1 Hasil Uji korelasi Kendalls Tau - b

Correlations

\begin{tabular}{|c|c|c|c|c|}
\hline & & & $\begin{array}{l}\text { tingkat } \\
\text { motivasi }\end{array}$ & $\begin{array}{l}\text { tingkat } \\
\text { prestasi } \\
\text { akademik }\end{array}$ \\
\hline \multirow[t]{2}{*}{$\begin{array}{l}\text { Kendall's } \\
\text { tau_b }\end{array}$} & tingkat motivasi & $\begin{array}{l}\text { Correlation } \\
\text { Coefficient } \\
\text { Sig. (2-tailed) } \\
N\end{array}$ & $\begin{array}{r}1,000 \\
. \\
110\end{array}$ & $\begin{array}{r}, 108 \\
, 237 \\
110\end{array}$ \\
\hline & $\begin{array}{l}\text { tingkat prestasi } \\
\text { akademik }\end{array}$ & $\begin{array}{l}\text { Correlation } \\
\text { Coefficient } \\
\text { Sig. (2-tailed) } \\
N\end{array}$ & $\begin{array}{r}, 108 \\
, 237 \\
110\end{array}$ & $\begin{array}{r}1,000 \\
. \\
110\end{array}$ \\
\hline
\end{tabular}

Berdasarkan output uji korelasi kendal tau-b diatas, diketahui nilai signifikansi (sig 2 tailed) antar variabel tingkat motivasi dan tingkat prestasi akademik adalah 0,237 . Nilai tersebut lebih besar dari taraf signifikansi yakni 0,05. Dengan demikian, hasil uji statistik tersebut menunjukkan bahwa tidak ada hubungan yang signifikan antara tingkat motivasi dan tingkat prestasi akademik. Dengan kata lain, mahasiswa yang mempunyai motivasi rendah terhadap pilihan program studinya tidak serta merta rendah pula prestasi akademiknya, begitu juga sebaliknya mahasiswa yang memiliki motivasi tinggi dalam memilih program studinya juga tidak serta merta tinggi prestasi akademiknya.

Hasil ini diperkuat oleh tingkat keeratan atau kekuatan hubungan antar variabel. Tabel 2 menunjukkan tingkat keeratan antar variabel yang dikategorikan menjadi lima, yakni sangat lemah. cukup, kuat, sangat kuat, dan sempurna.

Tabel 2 Kategori tingkat kekuatan korelasi

\begin{tabular}{|c|c|}
\hline Nilai Koefisien Korelasi & Kategori \\
\hline $0,00 \mathrm{~s} / \mathrm{d} 0,25$ & Sangat lemah \\
\hline $0,26 \mathrm{~s} / \mathrm{d} 0,50$ & Cukup \\
\hline $0,51 \mathrm{~s} / \mathrm{d} 0,75$ & Kuat \\
\hline $0,76 \mathrm{~s} / \mathrm{d} 0,99$ & Sangat kuat \\
\hline 1,00 & Sempurna \\
\hline
\end{tabular}

Berdasarkan tabel output uji korelasi Kendalls tau-b, diketahui nilai koefisien korelasi antara variabel tingkat motivasi dan variabel tingkat prestasi akademik adalah sebesar 0,108. Dengan demikian, dapat dinyatakan bahwa hubungan antara variabel tingkat motivasi dan variabel tingkat prestasi akademik adalah "sangat lemah". Dengan kata lain, dapat diinterpretasikan bahwa tidak ada hubungan yang signifikan antara motivasi pemilihan program studi dengan prestasi akademik, begitu juga sebaliknya prestasi akademik mahasiswa tidak ditentukan oleh motivasi dalam memilih program studi. 
Tujuan kedua dari penelitian ini adalah mendeskripsikan arah korelasi yang terjadi antara motivasi pemilihan program studi dengan prestasi akademik mahasiswa Politeknik Negeri Tanah Laut Tahun Ajaran 2018/2019. Arah korelasi/hubungan dilihat dari angka koefisien korelasi apakah hasilnya bernilai positif atau negatif. Berdasarkan tabel output, diketahui koefisien korelasi antara variabel tingkat motivasi dan variabel tingkat prestasi akademik adalah bernilai positif/searah.

Adapun hasil yang diperoleh pada penelitian ini tidaklah sejalan dengan apa yang diperoleh dari penelitian Abimayu (2013). Dalam skripsinya, ia meneliti hubungan antara minat terhadap fakultas dengan prestasi akademik mahasiswa. Hasilnya, ditemukan hubungan positif yang sangat signifikan antara minat terhadap fakultas dengan indeks prestasi kumulatif mahasiswa. Ini berarti semakin tinggi minat mahasiswa akan sebuah jurusan atau program studi, maka semakin tinggi nilai indeks prestasi kumulatif yang dapat diperolehnya. Begitu juga sebaliknya, jika minat mahasiswa terhadap jurusan atau program studi yang ia miliki rendah, maka semakin renda pula indeks prestasi kumulatif yang diperolehnya.

Penelitian berikutnya didapat dari Pravesti (2016). Dalam penelitiannya, diperoleh hasil bahwa pada mahasiswa minat dan motivasi belajar berpengaruh secara simultan dan positif terhadap prestasi akademik. Minat belajar berpengaruh secara langsung terhadap motivasi belajar dan minat belajar berpengaruh secara langsung terhadap prestasi akademik. Jalur tersebut didukung oleh koefisien total kontribusi minat belajar terhadap motivasi belajar sebesar 0,786. Sedangkan jalur minat belajar terhadap prestasi akademik sebesar 0,166. Pada variabel motivasi belajar juga memiliki pengaruh secara langsung terhadap prestasi akademik. Adapun koefisien jalur pada motivasi belajar terhadap prestasi sebesar 0,166 .

Prestasi akademik seorang mahasiswa diperoleh melalui proses belajar dari waktu ke waktu selama mengikuti kuliah. Tidak jauh beda dengan prestasi belajar, prestasi akademik seseorang dapat mengalami perubahan naik dan turun tergantung pada upaya dan kerja keras yang dilakukan. Motivasi yang mempengaruhi prestasi akademik adalah motivasi dalam mengikuti perkuliahan. Mereka yang memiliki motivasi tinggi, tekun, sungguh-sungguh dalam belajar, dan tetap semangat dalam menghadapi berbagai persoalan dan ujian wajar jika memiliki prestasi akademik yang tinggi, demikian pula sebaliknya. Bukan hanya motivasi saat pemilihan program studi. Oleh karena itu, korelasi/hubungan antara variabel tingkat motivasi dan variabel tingkat prestasi akademik adalah tidak signifikan, sangat lemah, tetapi searah.

\section{KESIMPULAN}

Tidak ada hubungan/korelasi yang signifikan antara motivasi pemilihan program studi dengan prestasi akademik mahasiswa Politeknik Negeri Tanah Laut Tahun Ajaran 2018/2019. Kekuatan korelasi yang terjadi antara keduanya berkategori sangat lemah. Arah korelasi yang terjadi antara motivasi pemilihan program studi dengan prestasi akademik mahasiswa Politeknik Negeri Tanah Laut Tahun Ajaran 2018/2019 adalah positif/searah, artinya mereka yang mempunyai motivasi tinggi terhadap program studi yang dipilih tidak selalu memiliki prestasi akademik yang juga tinggi. Adapun mereka yang memiliki motivasi rendah ternyata dapat memiliki prestasi yang tinggi.

\section{DAFTAR PUSTAKA}

Abimayu, G. (2013). Hubungan Antara Minat Terhadap Fakultas Dengan Prestasi Akademik Mahasiswa Fakultas Psikologi Universitas Muhammadiyah Surakarta (Thesis, Universitas Muhammadiyah Surakarta).

Adjani, S., \& Adam, H. (2012). Faktor-faktor yang mempengaruhi prestasi belajar mahasiswa pada mata kuliah pengantar akuntansi. Jurnal Ilmiah Mahasiswa FEB, 1(1). 
Catur, Pangestu Marlianto. (2018). Faktor-Faktor yang Memengaruhi Prestasi Akademik pada Mahasiswa Kedokteran Tahap Preklinik. Semarang: Undip Press.

Dzaki, Faiq Muhammad (2009). Model Pembelajaran Induktif - Struktur Sosial dan Peran Guru.

Notoatmodjo, Soekidjo. (2010). Ilmu Perilaku Kesehatan. Jakarta: Rineka Cipta.

Pravesti, C. A. (2016). Hubungan Minat Belajar Dan Motivasi Belajar Terhadap Prestasi Akademik Mahasiswa Jurusan Bimbingan \& Konseling Universitas PGRI Adi Buana Surabaya. HELPER: Jurnal Bimbingan dan Konseling, 32(2).

Slameto. (2010). Belajar dan Faktor-Faktor yang Mempengaruhinya. Jakarta: Rineka Cipta.

Sugiyanto, S., \& Himawan, H. (2009). Penentuan kompetensi mahasiswa berdasarkan prestasi akademik, sertifikasi kompetensi, minat, dan kegiatan pendukung. Jurnal Teknologi Informasi, 5(2), 766-774.

Sugiyono. (2017). Metode Penelitian Kuantitatif, Kualitatif, dan R\&D. Bandung : Alfabeta, CV.

Syah Muhibbin. (2011). Psikologi Belajar. Jakarta : PT Raja Grapindo Persada. 